\title{
Age and Gender Dependent Nutrient Composition of Feather and Feather-Free Body Fractions in Meat-Type Chickens
}

\author{
Christian Wecke, Daulat Rehman Khan, Angela Sünder, Frank Liebert \\ Division Animal Nutrition Physiology, Department of Animal Sciences, Georg-August-University of Göttingen, \\ Göttingen, Germany \\ Email: flieber@gwdg.de
}

How to cite this paper: Wecke, C., Khan, D.R., Sünder, A. and Liebert, F. (2018) Age and Gender Dependent Nutrient Composition of Feather and Feather-Free Body Fractions in Meat-Type Chickens. Open Journal of Animal Sciences, 8, 74-86. https://doi.org/10.4236/ojas.2018.81006

Received: October 24, 2017

Accepted: January 7, 2018

Published: January 10, 2018

Copyright $\odot 2018$ by authors and Scientific Research Publishing Inc. This work is licensed under the Creative Commons Attribution International License (CC BY 4.0).

http://creativecommons.org/licenses/by/4.0/

(c) (i) Open Access

\begin{abstract}
The objective of this research was to update current results about the nutrient composition of broiler chickens during the growth period up to market age. Two growth experiments were conducted for assessing the nutrient content of feathers and feather-free body of meat-type chickens (Ross 308). Both male and female birds were reared under uniform management conditions (floor pens; 15 pens per gender; 5 birds per pen). Experimental diets both for the starter (day 1 to 22 ) and the grower period (day 22 to 36 ) were based on corn, wheat, soybean meal, soybean protein concentrate and well balanced with feed amino acids. The feed protein quality was adapted to the ideal amino acid ratio and equated within both of the feeding periods by adjusting a constant mixture of the feed proteins. Each 15 birds per gender ( 3 pens of 5 birds) were selected and subsequently fasted for $24 \mathrm{~h}$ before quantitative de-feathering both at start of the experiment and further on weekly up to the end of the $5^{\text {th }}$ week. Nutrient content was determined in representative samples of the feather and feather-free body fraction. In the feather dry matter (DM) very high crude protein (CP) concentrations (>96\%) with low age-dependent and insignificant gender-specific differences were observed. In spite, a relatively high variation of $\mathrm{CP}$ content in the DM of feather-free body was found. Depending on age, the body $\mathrm{CP}$ significantly decreased with increasing age, but male birds yielded higher $(p<0.001)$ CP content. The crude lipid content of the feather-free and whole empty body significantly increased with age and was higher in female as compared to male birds $(p<0.001)$. Depending on age and gender, the crude ash content both in feathers and feather-free body of modern fast-growing chickens was rather low and with very low variation.
\end{abstract}

\section{Keywords}

Growing Chickens, Feather Composition, Body Composition, Age, Gender 


\section{Introduction}

The fast breeding progress in meat-type chicken [1] [2] [3] [4] also has impacts on body composition as compared to birds of earlier decades. Consequently, body composition data of actual broiler genotypes provide important information for further improvement of optimized dietary protein and amino acid supply. In addition, further minimizing of $\mathrm{N}$ excretion according to the future demands is supported [5]. Modern broiler genotypes require significantly higher energy and nutrient concentrations in the diet to optimize both performance data (body weight gain, body protein deposition) and efficiency of protein utilization [6].

Generally, the database for age dependent nutrient composition of whole body and body fractions like feathers in current genotypes of meat-type chickens is scarce. Mostly, de-feathered carcasses were analyzed. The present study aimed to provide actual results about age-dependent changes in whole body composition based on analyzed feathers and feather-free bodies from male and female modern meat-type chicken, making use of a recently reported database [7].

\section{Materials and Methods}

Two consecutive growth experiments were conducted at the facilities of the Division Animal Nutrition Physiology, Department of Animal Sciences at Georg-August-University Göttingen and approved by the Lower Saxony Federal Office for Consumer Protection and Food Safety (LAVES), Germany. The study utilized a total of 180 growing broiler chickens (male to female birds = 1:1) and the methodical background as described in detail in a previous publication [7]. The present paper only completes this information which is needed for further understanding.

\subsection{Animals and Housing}

Day old meat-type chickens (ROSS 308) were obtained from a commercial hatchery and kept together in a floor pen on wood shavings. At next day (d1) averaged weighed birds were randomly allotted to 15 pens per gender (each 5 birds per pen) and kept under uniform management and feeding conditions (starter period: 1 to $22 \mathrm{~d}$; grower period: 22 to $36 \mathrm{~d}$ ). Further details were reported elsewhere [7].

\subsection{Diets and Feeding}

Both the starter and grower diet [7] was based on corn, wheat and soybean meal, soybean protein concentrate and crystalline feed amino acids as main ingredients. Diet formulation aimed to meet current recommendations and was adjusted close to the ideal amino acid ratios. A constant mixture of the dietary protein sources yielded equal feed protein quality during both of the feeding periods.

\subsection{Collection and Sampling}

At start of the experiment and weekly up to the end of the 5th week, 15 male and 
female chickens ( 3 pens per week and gender) were selected by body weight (BW). Selected birds had full access to drinking water, were fasted for 24 hours for emptying the digestive tract to yield an "empty body mass". According to animal welfare regulations, these birds were subsequently euthanized by $\mathrm{CO}_{2}$ inhalation. Each sample of quantitatively collected feathers and of feather-free empty body was separately stored in plastic bags at $-20^{\circ} \mathrm{C}$ for further processing as previously described in detail [7].

\subsection{Chemical Analyses}

Feed ingredients, diets, feathers and feather-free empty bodies were analysed in duplicates according to the German standard procedures [8]. $\mathrm{N}$ analyses were conducted by DUMAS-method (LECO ${ }^{\circ}$ TruMac, LECO Instrument $\mathrm{GmbH}$, Kirchheim, Germany) and crude protein (CP) was calculated by factor as $\mathrm{N} \times$ 6.25. The crude lipid (CL) fraction of feed samples was analysed following $\mathrm{HCl}$ hydrolysis. According to Fuller [9], the body of growing animals substantially consists of $\mathrm{CP}, \mathrm{CL}$ and crude ash (CA). In consequence, the CL content of the body fractions was calculated by difference (100-CP-CA) and expressed as percent of dry matter (DM). This procedure is supported by Hancock et al. [10], who observed a highly significant regression coefficient $(r=0.997)$ between body CL content as determined by Soxhlet extraction and calculated by difference as described above.

\subsection{Statistical Analyses}

Statistical analyses run with SPSS software package (Version 23.0 for Windows; IBM SPSS Statistics Inc., Chicago, IL, USA). Two-way analysis of variance (ANOVA) was performed to compare the means and standard deviations of variables depending both on age and gender of broiler chickens as main effects, inclusive their interactions. Verification of variance homogeneity (evaluated by Levene-Test) and identification of significant differences $(p \leq 0.05)$ applied Games-Howell test and Tukey post-hoc test, respectively. Furthermore, regression analyses were utilized to demonstrate the age-dependent variation of $\mathrm{CP}$, $\mathrm{CL}$ and CA contents in feathers, feather-free and whole empty body of male and female birds.

\section{Results}

The age and gender dependent data for development of feather and body mass were already reported [7] and applied for current calculations. Table 1 summarizes the mean $\mathrm{CP}$ contents of feathers and both of body fractions depending on age and gender, respectively.

Generally, a very high CP content (>96\%) was observed in the DM of feathers. The CP content in the feather DM exceeded $100 \%$ both in day old and male birds at $8 \mathrm{~d}$ of age, indicating that the applied factor $(\mathrm{N} \times 6.25)$ could be misleading. In addition, the $\mathrm{CP}$ content in feather $\mathrm{DM}$ was significantly affected by 
Table 1. Crude protein content of body fractions depending on age and gender of broiler chickens. ${ }^{1}$

\begin{tabular}{|c|c|c|c|c|c|c|}
\hline \multirow{2}{*}{ Age (d) } & \multicolumn{2}{|c|}{ Feathers $^{2}(\% \mathrm{DM})$} & \multicolumn{2}{|c|}{ Feather-free body (\% DM) } & \multicolumn{2}{|c|}{ Empty body $^{3}(\% \mathrm{DM})$} \\
\hline & Male & Female & Male & Female & Male & Female \\
\hline 1 & $(100.2)$ & $(102.4)$ & 71.2 & 70.4 & 74.5 & 73.3 \\
\hline 8 & $(100.7)$ & 98.5 & 67.7 & 62.5 & 69.2 & 64.1 \\
\hline 15 & 95.8 & 96.8 & 65.2 & 61.5 & 66.3 & 63.4 \\
\hline 22 & 97.7 & 97.0 & 65.4 & 60.5 & 67.0 & 62.5 \\
\hline 29 & 98.6 & 98.2 & 63.4 & 58.8 & 65.2 & 61.3 \\
\hline $36^{4}$ & 99.3 & 99.0 & 64.0 & 56.3 & 66.2 & 59.5 \\
\hline Mean & 98.7 & 98.7 & 66.2 & 61.7 & 68.1 & 64.0 \\
\hline \multirow[t]{2}{*}{ SD } & 2.2 & 2.0 & 3.2 & 4.6 & 3.6 & 4.6 \\
\hline & \multicolumn{6}{|c|}{ Significance levels (p) of two-way ANOVA } \\
\hline Age (A) & \multicolumn{2}{|c|}{$<0.001$} & \multicolumn{2}{|c|}{$<0.001$} & \multicolumn{2}{|c|}{$<0.001$} \\
\hline Gender $(\mathrm{G})$ & \multicolumn{2}{|c|}{$=0.886$} & \multicolumn{2}{|c|}{$<0.001$} & \multicolumn{2}{|c|}{$<0.001$} \\
\hline$A \times G$ & \multicolumn{2}{|c|}{$=0.106$} & \multicolumn{2}{|c|}{$=0.026$} & \multicolumn{2}{|c|}{$=0.066$} \\
\hline
\end{tabular}

$\mathrm{DM}=$ dry matter, $\mathrm{SD}=$ standard deviation of means, $\mathrm{A} \times \mathrm{G}=$ interaction between age and gender. ${ }^{1} \mathrm{n}=3$ pooled samples of each five birds per age period and gender. ${ }^{2} \mathrm{At} 1 \mathrm{~d}$ of age only one pooled feather sample of each gender due to the low feather yield per bird. ${ }^{3}$ Whole body mass following $24 \mathrm{~h}$ feed deprivation. ${ }^{4}$ Final body mass of male birds was determined at $35 \mathrm{~d}$ of age.

age $(p<0.001)$, in spite of rather small differences in the observed CP content. However, no gender-specific effect of age on feather CP content was found $(p>$ 0.05). Otherwise, we observed a high age-dependent variation of the CP content in the DM of feather-free body (from $71 \%$ to $56 \%$ ) and whole empty body (from $74 \%$ to $60 \%)$. The CP concentration in both of these body fractions decreased significantly $(p<0.001)$ with increasing of age and male birds yielded steadily higher CP contents as compared to females $(p<0.001)$.

In contrast, the CL content both in the feather-free and the whole empty body increased significantly with age of birds $(p<0.001)$. Female birds yielded higher $(p<0.001)$ CL content in both of the fractions (Table 2). Furthermore, for CL data a significant two-way interaction among the variables age and gender $(p<$ 0.05 ) was observed.

The CA content in the feather DM initially increased up to $15 \mathrm{~d}$ of age and afterwards decreased again up to the end of the experiment $(p<0.001)$ in both genders (Table 3). As compared to male birds, feathers of female birds, especially at $15 \mathrm{~d}$ of age, contained significantly lower CA contents $(p<0.001)$. The highest CA contents $(9.4 \%$ and $8.5 \%$ of DM) were observed in the feather-free and empty body of day old chickens. In male birds, the CA concentration decreased up to $15 \mathrm{~d}$ of age in both body fractions. Afterwards, elevated CA data were observed with increasing of age. In contrast, depending on age the CA content in the feather-free and empty body DM of female birds declined continuously $(p<0.001)$. In addition, significant two-way interactions between age and gender $(p<0.01)$ were observed. 
Table 2. Crude lipid content of body fractions depending on age and gender of broiler chickens. ${ }^{1}$

\begin{tabular}{|c|c|c|c|c|}
\hline \multirow{2}{*}{ Age (d) } & \multicolumn{2}{|c|}{ Feather-free body (\% DM) } & \multicolumn{2}{|c|}{ Empty body $^{2}(\% \mathrm{DM})$} \\
\hline & Male & Female & Male & Female \\
\hline 1 & 19.39 & 20.19 & 17.06 & 18.04 \\
\hline 8 & 23.72 & 29.22 & 22.55 & 27.87 \\
\hline 15 & 26.56 & 30.17 & 25.65 & 28.69 \\
\hline 22 & 26.03 & 31.21 & 24.74 & 29.59 \\
\hline 29 & 27.88 & 33.15 & 26.41 & 31.04 \\
\hline $36^{3}$ & 27.27 & 36.03 & 25.51 & 33.34 \\
\hline Mean & 25.14 & 29.99 & 23.65 & 28.09 \\
\hline \multirow[t]{2}{*}{ SD } & 3.42 & 5.16 & 3.65 & 5.06 \\
\hline & \multicolumn{4}{|c|}{ Significance levels (p) of two-way ANOVA } \\
\hline Age (A) & \multicolumn{2}{|c|}{$<0.001$} & \multicolumn{2}{|c|}{$<0.001$} \\
\hline Gender $(G)$ & \multicolumn{2}{|c|}{$<0.001$} & \multicolumn{2}{|c|}{$<0.001$} \\
\hline$A \times G$ & \multicolumn{2}{|c|}{$=0.013$} & \multicolumn{2}{|c|}{$=0.025$} \\
\hline
\end{tabular}

$\mathrm{DM}=$ dry matter, $\mathrm{SD}=$ standard deviation of means, $\mathrm{A} \times \mathrm{G}=$ interaction between age and gender. ${ }^{1} \mathrm{n}=3$ pooled samples of each five birds per age period and gender. ${ }^{2}$ Whole body mass following $24 \mathrm{~h}$ feed deprivation. ${ }^{3}$ Final body mass of male birds was determined at $35 \mathrm{~d}$ of age.

Table 3. Crude ash content of body fractions depending on age and gender of broiler chickens. ${ }^{1}$

\begin{tabular}{|c|c|c|c|c|c|c|}
\hline \multirow{2}{*}{ Age (d) } & \multicolumn{2}{|c|}{ Feathers $^{2}$ (\% DM) } & \multicolumn{2}{|c|}{ Feather-free body (\% DM) } & \multicolumn{2}{|c|}{ Empty body ${ }^{3}$ (\% DM) } \\
\hline & Male & Female & Male & Female & Male & Female \\
\hline 1 & 1.03 & 1.12 & 9.38 & 9.38 & 8.43 & 8.63 \\
\hline 8 & 1.55 & 1.97 & 8.56 & 8.31 & 8.23 & 8.02 \\
\hline 15 & 2.55 & 2.02 & 8.28 & 8.29 & 8.07 & 7.96 \\
\hline 22 & 2.06 & 1.78 & 8.58 & 8.28 & 8.26 & 7.93 \\
\hline 29 & 1.70 & 1.47 & 8.72 & 8.07 & 8.36 & 7.64 \\
\hline $36^{4}$ & 1.49 & 1.38 & 8.71 & 7.63 & 8.25 & 7.16 \\
\hline Mean & 1.73 & 1.62 & 8.70 & 8.33 & 8.27 & 7.89 \\
\hline \multirow[t]{2}{*}{ SD } & 0.49 & 0.34 & 0.41 & 0.56 & 0.24 & 0.47 \\
\hline & \multicolumn{6}{|c|}{ Significance levels (p) of two-way ANOVA } \\
\hline Age (A) & \multicolumn{2}{|c|}{$<0.001$} & \multicolumn{2}{|c|}{$<0.001$} & \multicolumn{2}{|c|}{$<0.001$} \\
\hline Gender (G) & \multicolumn{2}{|c|}{$<0.001$} & \multicolumn{2}{|c|}{$<0.001$} & \multicolumn{2}{|c|}{$<0.001$} \\
\hline$A \times G$ & \multicolumn{2}{|c|}{$<0.001$} & \multicolumn{2}{|c|}{$=0.003$} & \multicolumn{2}{|c|}{$<0.001$} \\
\hline
\end{tabular}

$\mathrm{DM}=$ dry matter, $\mathrm{SD}=$ standard deviation of means, $\mathrm{A} \times \mathrm{G}=$ interaction between age and gender. ${ }^{1} \mathrm{n}=3$ pooled samples of each five birds per age period and gender. ${ }^{2}$ At $1 \mathrm{~d}$ of age only one pooled feather sample of each gender due to the low feather yield per bird. ${ }^{3}$ Whole body mass following $24 \mathrm{~h}$ feed deprivation. ${ }^{4}$ Final body mass of male birds was determined at $35 \mathrm{~d}$ of age. 
The age-dependent variation of $\mathrm{CP}, \mathrm{CL}$ and $\mathrm{CA}$ contents in feathers, feather-free and whole empty body of male and female birds was validated by regression analyses. In all cases, the selection of a quadratic regression model (polynomial function of degree 2) yielded superior curve approximation with highest correlation coefficient $(r)$ due to the non-linear course of experimental data as function of the individual empty BW. Relationships between empty BW and nutrient contents of different body fractions were summarized in Table 4. Exemplary, the variation of nutrient contents in the empty body of male and female birds throughout the entire growth period up to market age is delineated in Figure 1. All curves were fitted according to specified equations (Table 4). The CA content of the whole empty body DM of male birds (bold line) runs nearly parallel to $\mathrm{x}$-axis as demonstrated by the very low correlation coefficient $(\mathrm{r}=$ 0.0291).

Table 5 shows the partitioning of the CP and CA contents within the feather and feather-free body fractions expressed as percentage of the whole empty BW, respectively. The minor BW differences as compared to previously reported data

Table 4. Correlations among empty body mass data (x) and crude nutrient contents (y) in different body fractions of male (m) and female (f) broiler chickens. ${ }^{1}$

\begin{tabular}{ccccc}
\hline y & $\mathrm{a}$ & $\mathrm{b}$ & $\mathrm{c}$ & $\mathrm{r}$ \\
\hline CP (\% DM) in & & & & \\
Feathers (m +f) & 0.000002 & -0.00555 & 100.360 & 0.5721 \\
Feather-free body (m) & 0.000002 & -0.00762 & 69.663 & 0.7573 \\
Feather-free body (f) & 0.000002 & -0.01022 & 67.365 & 0.8552 \\
Empty body (m) & 0.000003 & -0.00944 & 72.060 & 0.7333 \\
Empty body (f) & 0.000003 & -0.01119 & 69.708 & 0.8110 \\
CL (\% DM) in & & & & \\
Feather-free body (m) & -0.000002 & 0.00825 & 21.433 & 0.7309 \\
Feather-free body (f) & -0.000003 & 0.01118 & 23.709 & 0.8507 \\
Empty body (m) & -0.000003 & 0.00941 & 19.681 & 0.7142 \\
Empty body (f) & -0.000003 & 0.01178 & 21.915 & 0.8192 \\
CA (\% DM) in & & & & 0.037 \\
Feathers (m) & -0.0000006 & 0.00138 & 1.395 & 0.6221 \\
Feathers (f) & -0.0000003 & 0.00057 & 1.541 & 0.5255 \\
Feather-free body (m) & 0.0000002 & -0.00063 & 8.904 & 0.3261 \\
Feather-free body (f) & 0.0000002 & -0.00096 & 8.926 & 0.7893 \\
Empty body (m) & -0.00000001 & 0.00003 & 8.258 & 0.0291 \\
Empty body (f) & 0.00000003 & -0.00058 & 8.376 & 0.8772 \\
\hline
\end{tabular}

$\mathrm{CP}=$ crude protein, $\mathrm{CL}=$ crude lipids, $\mathrm{CA}=$ crude ash, $\mathrm{DM}=$ dry matter. ${ }^{1}$ During growth period from 1 $36 \mathrm{~d}$ of age at 42 to $2300 \mathrm{~g}$ individual empty body weight, relationships are described by equation $\mathrm{y}=\mathrm{ax}^{2}+$ $\mathrm{bx}+c$, where $\mathrm{y}=$ nutrient content $(\%$ of $\mathrm{DM}), \mathrm{x}=$ whole empty body weight $(\mathrm{g} / \mathrm{bird})$, $\mathrm{a}$ and $\mathrm{b}=$ regression coefficients (slope of the function), $c=$ intercept (intersection point of $y$-axis), $r=$ correlation coefficient. 


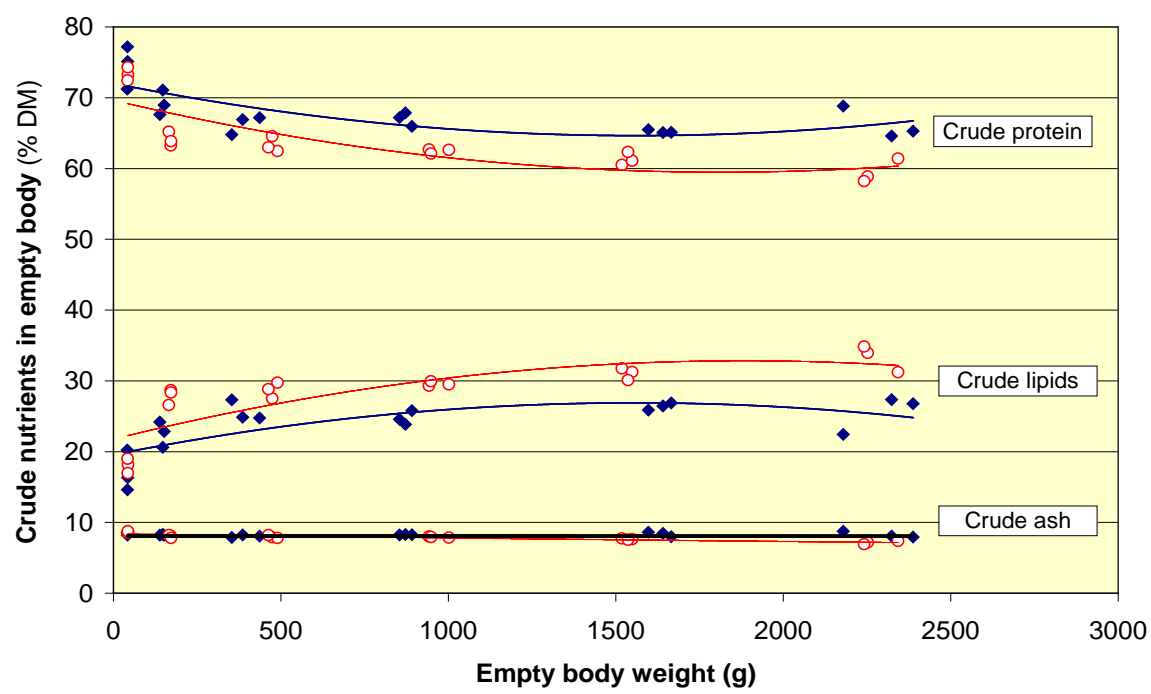

Figure 1. Crude nutrient contents in the empty body dry matter (DM) of male [^] and female [o] broiler chickens dependent on empty body weight.

Table 5. Proportions of crude protein and crude ash in the feather and feather-free body fraction as related to the whole empty body content of male (m) and female (f) broiler chickens depending on age. ${ }^{1}$

\begin{tabular}{|c|c|c|c|c|c|c|c|c|c|c|}
\hline \multirow{3}{*}{ Age (d) } & \multirow{2}{*}{\multicolumn{2}{|c|}{$\begin{array}{l}\text { Empty body } \\
\text { mass }^{2}(\mathrm{~g})\end{array}$}} & \multicolumn{4}{|c|}{ Crude protein (\%) in } & \multicolumn{4}{|c|}{ Crude ash (\%) in } \\
\hline & & & \multicolumn{2}{|c|}{ Feathers } & \multicolumn{2}{|c|}{$\begin{array}{c}\text { Feather-free } \\
\text { body }\end{array}$} & \multicolumn{2}{|c|}{ Feathers } & \multicolumn{2}{|c|}{$\begin{array}{c}\text { Feather-free } \\
\text { body }^{2}\end{array}$} \\
\hline & $\mathrm{m}$ & $\mathrm{f}$ & $\mathrm{m}$ & $\mathrm{f}$ & $\mathrm{m}$ & $\mathrm{f}$ & $\mathrm{m}$ & $\mathrm{f}$ & $\mathrm{m}$ & $\mathrm{f}$ \\
\hline 1 & 42 & 43 & 15.2 & 12.7 & 84.8 & 87.3 & 1.4 & 1.2 & 98.6 & 98.8 \\
\hline 8 & 146 & 169 & 6.7 & 7.0 & 93.3 & 93.0 & 0.9 & 1.1 & 99.1 & 98.9 \\
\hline 15 & 392 & 475 & 5.3 & 7.8 & 94.7 & 92.2 & 1.2 & 1.3 & 98.8 & 98.7 \\
\hline 22 & 872 & 964 & 7.3 & 8.4 & 92.7 & 91.6 & 1.2 & 1.2 & 98.8 & 98.8 \\
\hline 29 & 1634 & 1534 & 7.9 & 10.3 & 92.1 & 89.7 & 1.1 & 1.2 & 98.9 & 98.8 \\
\hline $36^{3}$ & 2297 & 2279 & 9.4 & 12.3 & 90.6 & 87.7 & 1.1 & 1.4 & 98.9 & 98.6 \\
\hline Mean & 1004 & 1019 & 8.7 & 9.8 & 91.3 & 90.2 & 1.1 & 1.2 & 98.8 & 98.8 \\
\hline \multirow[t]{2}{*}{ SD } & 839 & 799 & 3.4 & 2.3 & 3.4 & 2.3 & 0.2 & 0.1 & 0.2 & 0.1 \\
\hline & \multicolumn{10}{|c|}{ Significance levels (p) of two-way ANOVA } \\
\hline A & \multicolumn{2}{|c|}{$<0.001$} & \multicolumn{2}{|c|}{$<0.001$} & \multicolumn{2}{|r|}{$<0.001$} & \multicolumn{2}{|c|}{$=0.001$} & \multicolumn{2}{|c|}{$=0.001$} \\
\hline G & \multicolumn{2}{|c|}{$=0.746$} & \multicolumn{2}{|c|}{$<0.001$} & \multicolumn{2}{|r|}{$<0.001$} & \multicolumn{2}{|c|}{$=0.012$} & \multicolumn{2}{|c|}{$=0.012$} \\
\hline$A \times G$ & \multicolumn{2}{|c|}{$=0.006$} & \multicolumn{2}{|c|}{$<0.001$} & \multicolumn{2}{|r|}{$<0.001$} & \multicolumn{2}{|c|}{$=0.005$} & \multicolumn{2}{|c|}{$=0.005$} \\
\hline
\end{tabular}

$\mathrm{SD}=$ standard deviation, $\mathrm{A}=$ age, $\mathrm{G}=$ gender, $\mathrm{A} \times \mathrm{G}=$ interaction between age and gender. ${ }^{1}$ Calculations based on data summarized in Table 1 and Table 3 and on dry matter contents of both fractions [7]. ${ }^{2}$ Whole body resp. feather free body following $24 \mathrm{~h}$ feed deprivation. ${ }^{3}$ Final body mass of male birds was determined at $35 \mathrm{~d}$ of age.

[7] are explainable due to elimination of some feather percentage outliners. In the present investigation, both the feather and feather-free body homogenates of all individual birds were analyzed and included in the data evaluation. Due to 
the high DM and CP contents in feathers of day old chickens, the feather CP proportion as related to the whole empty body CP was between $13 \%$ and $15 \%$. Depending on gender the partial proportion of the feather CP significantly decreased down to $5 \%-7 \%$ at the end of the first resp. second week of age. Subsequently, the $\mathrm{CP}$ partition in the feather fraction increased continuously. Female birds achieved the initial level of this proportion at $36 \mathrm{~d}$ of age. The development of the feather-free body protein fraction was inversely as compared to feather $\mathrm{CP}$. Contrary to these observations, the detected significant age and gender-specific differences of the CA partitioning in the feather and feather-free body fraction were very low and undirected.

\section{Discussion}

Feathers of growing meat-type chickens are rich in CP, but low in CL and CA. About $85 \%-90 \%$ of the total feather protein is feather keratin, a durable fibrous scleroprotein [11]. According to earlier reports [12] [13] [14] [15], scleroproteins in feathers, hairs, wool and horn contain a high percentage of $\mathrm{N}(15.0 \%$ to 16.8\%). Due to our current results, in few days old birds the CP content in the feather DM may even exceed $100 \%$ when the common calculation factor $(\mathrm{N} \times$ $6.25)$ is applied. Harrap and Woods [14] also reported more than $16 \% \mathrm{~N}$ (i.e. $>100 \% \mathrm{CP}$ ) in the feather DM of laying hens. Literature data vary between more than $90 \%$ and close to $100 \% \mathrm{CP}$ in the feather DM of growing chickens [16]-[21].

Generally, the CP content of chicken feathers increases with increasing age of birds [10] [16] due to the decline of moisture content. The significant age-dependent effect on CP content in the feather DM (Table 1) is in agreement with Stilborn et al. [19], but due to the observed variation of marginal importance. Therefore, in line with several reports [10] [18] [22], it is justified to conclude that feather protein content provides a rather constant proportion of the DM throughout the entire growth period. Accordingly, consistent gender and genotype effects for feather CP content of growing chickens were not observed [10] [18] [19]. Nevertheless, Leclercq et al. [23] reported that the feather protein content was both affected by genotype (genetically lean or fat chickens at $42 \mathrm{~d}$ of age) and dietary lysine level.

Further nutrients in the feather fraction of growing chickens are of low quantitative importance. Stilborn et al. [18] and Conde-Aguilera et al. [21] reported $1.3 \%$ to $2.5 \%$ CL in the feather DM. Slightly higher contents (2\% to $4 \%$ CL of feather DM) were analysed by Lehmann [16]. The currently applied calculation of the CL contents is not useful to update database of feather lipid contents.

Analysed CA data (Table 3) are in good agreement with previous results [16] [18] [21] indicating the range of $0.5 \%$ to $3 \% \mathrm{CA}$ in the feather DM. In contrast to our observations, no clear dependency on age, gender and genotype was observed by Stilborn et al. [18].

As compared to feathers, earlier studies reported a considerably higher variability of nutrient composition data both in the feather-free and the whole 
empty body of growing chickens. Variations of feed energy density and voluntary feed consumption impact on body composition [24] [25] [26] [27] [28]. In addition, suboptimal dietary protein and inadequate dietary AA balance lower the body protein content, but enhance the body fat content (e.g. [3] [21] [23] [25]-[33]).

Furthermore, significant genotype-dependent body composition data need to be considered (e.g. [1] [2] [3] [18] [23] [29]-[37]). Increased growth rate of modern meat-type chickens is accompanied with higher body CL contents, a response which can be related to selection process for faster growing birds [1].

According to our observations (Table 1), the lower body CP content of female meat-type chicken is reported in numerous studies [18] [31] [34]-[39]. Furthermore, higher accumulation of abdominal fat and total body fat deposition in female birds is well known [1] [2] [3] [10] [18] [29] [31] [33] [34] [36] [38] [39]. Our data (Table 3, Figure 1) support these gender-specific effects. Furthermore, age dependent changes of total body composition of broiler chicken [18] [22] [25] [34] [35] [36] [37] [39] are in line with our results (Table 2, Figure 1) and confirm that the protein content in the body DM significantly declines with increasing age of birds. The observed age-dependent body protein content was inversely related to the body DM data [7].

According to literature data [2] [3] [18] [21] [22] [25] [28] [35] [36] [38] [39] we also found that the CL content both in the feather-free and whole empty body increased with increasing age of growing chickens $(p<0.001)$. In agreement with observations of Chambers et al. [1] and Havenstein et al. [2], the body CA content in the modern birds tended to be lower [3], but inconsistent data about CA contents in the body were reported.

Depending on energy and AA supply, genotype, gender and age only marginal differences in the body CA contents were reported [1] [10] [21] [22] [31] [36] [39]. However, both Somes and Johnson [34] and Havenstein et al. [2] [3] observed significantly different genotype-specific CA contents in broilers. Accordingly, we analysed significantly different $(p<0.001)$ CA contents dependent on gender and age both in the feather-free and whole empty body fraction (Table 3). In agreement with Stilborn et al. [18] significantly higher body CA contents were analysed in male vs. female birds, especially with advancing age. In contrast, Moran and Bilgili [40] observed lower CA contents in the carcass of male birds.

Generally, a high variation of published body composition data was observed. In addition to the factors of influence as discussed above, a valid reference (whole-body with or without gastrointestinal content, empty body or feather-free body following different times of feed removal, carcass with internal organs and viscera or commercial broiler carcass for the market) is very important to improve comparability of body composition data.

\section{Conclusions}

The $\mathrm{CP}(\mathrm{N} \times 6.25)$ content in the feather DM of fast-growing meat-type chick- 
ens is independent on gender very high $(>96 \%)$ and rather constant during the growing period up to market weight. Contrary, the feather DM is low in CL and CA. Minor differences depending on age and gender are negligible. The CP contents both in the feather-free and whole empty body DM vary inversely with the CL concentration. Body CP decreased and body CL increased as age of birds is increasing. Dependent on age and gender significant differences were detected for body ash contents, but with very low variation. Provided equations (Table 4) are available for calculation of nutrient contents in the feather and feather-free body fractions and in the whole empty body of modern meat-type chickens dependent on individual empty BW and gender. The present data basis is well suited to clarify the background for previously reported age-dependent and partially observed gender-specific differences regarding body composition of meat-type chickens.

In conclusion, the current study provides the evidence that the described procedure for modelling of body composition based on nutrient contents of feathers and feather-free empty body yields reliable data for estimation of deposition and utilization of nutrients in growing chickens. This remains as an important precondition for valid evaluation of nutrient requirements by application of factorial methods.

\section{References}

[1] Chambers, J.R., Gavora, J.S. and Fortin, A. (1981) Genetic Changes in Meat-Type Chickens in the Last Twenty Years. Canadian Journal of Animal Science, 61, 555-563. https://doi.org/10.4141/cjas81-067

[2] Havenstein, G.B., Ferket, P.R., Scheideler, S.E. and Rives, D.V. (1994) Carcass Composition and Yield of 1991 vs. 1957 Broilers When Fed "Typical" 1957 and 1991 Broiler Diets. Poultry Science, 73, 1795-1804. https://doi.org/10.3382/ps.0731795

[3] Havenstein, G.B., Ferket, P.R. and Qureshi, M.A. (2003) Carcass Composition and Yield of 1957 versus 2001 Broilers When Fed Representative 1957 and 2001 Broiler Diets. Poultry Science, 82, 1509-1518. https://doi.org/10.1093/ps/82.10.1509

[4] Schmidt, C.J., Persia, M.E., Feierstein, E., Kingham, B. and Saylor, W.W. (2009) Comparison of a Modern Broiler Line and a Heritage Line Unselected Since the 1950s. Poultry Science, 88, 2610-2619. https://doi.org/10.3382/ps.2009-00055

[5] Liebert, F. (2017) Further Progress Is Needed in Procedures for the Biological Evaluation of Dietary Protein Quality in Pig and Poultry Feeds. Archives Animal Breeding, 60, 259-270. https://doi.org/10.5194/aab-60-259-2017

[6] Wecke, C., Pastor, A. and Liebert, F. (2016) Validation of the Lysine Requirements as Reference Amino Acid for Ideal In-Feed Amino Acid Ratios in Modern Fast Growing Meat-Type Chickens. Open Journal of Animal Sciences, 6, 185-194. https://doi.org/10.4236/ojas.2016.63024

[7] Wecke, C., Khan, D.R., Sünder, A. and Liebert, F. (2017) Age and Gender Depending Growth of Feathers and Feather-free Body in Modern Fast Growing Meat-Type Chickens. Open Journal of Animal Sciences, 7, 376-392.

https://doi.org/10.4236/ojas.2017.74029

[8] Naumann, C. and Bassler, R. (1976-2004) Die chemische Untersuchung von Fut- 
termitteln. [The Chemical Analysis of Feedstuffs.] Methodenbuch, Vol. III, VDLUFA-Verlag, Darmstadt.

[9] Fuller, M.F., Ed. (2004) The Encyclopedia of Farm Animal Nutrition. CABI Publishing, Wallingford, Oxon. https://doi.org/10.1079/9780851993690.0000

[10] Hancock, C.E., Bradford, G.D., Emmans, G.C. and Gous, R.M. (1995) The Evaluation of the Growth Parameters of Six Strains of Commercial Broiler Chickens. British Poultry Science, 36, 247-264. https://doi.org/10.1080/00071669508417773

[11] Harrap, B.S. and Woods, E.F. (1964) Soluble Derivatives of Feather Keratin. 2. Molecular Weight and Conformation. Biochemical Journal, 92, 19-26. https://doi.org/10.1042/bj0920019

[12] Block, R.J. (1939) The Composition of Keratins. The Amino Acid Composition of Hair, Wool, Horn, and Other Eukeratins. Journal of Biological Chemistry, 128, 181-186.

[13] Graham, C.E., Waitkoff, H.K. and Hier, S.W. (1949) The Amino Acid Content of Some Scleroproteins. Journal of Biological Chemistry, 177, 529-532.

[14] Harrap, B.S. and Woods, E.F. (1964) Soluble Derivatives of Feather Keratin. 1. Isolation, Fractionation and Amino Acid Composition. Biochemical Journal, 92, 8-18. https://doi.org/10.1042/bj0920008

[15] Harrap, B.S. and Woods, E.F. (1967) Species Differences in the Protein of Feathers. Comparative Biochemistry and Physiology, 20, 449-460.

https://doi.org/10.1016/0010-406X(67)90260-5

[16] Lehmann, F. (1939) Schlachtversuche mit Masthühnern. [Slaughtering Studies with Fattening Fowls.] Archiv für Geflügelkunde, 13, 1-36.

[17] Fisher, M.-L., Leeson, S., Morrison, W.D. and Summers, J.D. (1981) Feather Growth and Feather Composition of Broiler Chickens. Canadian Journal of Animal Science, 61, 769-773. https://doi.org/10.4141/cjas81-093

[18] Stilborn, H.L., Moran, Jr., E.T., Gous, R.M. and Harrison, M.D. (1994) Experimental Data for Evaluating Broiler Models. The Journal of Applied Poultry Research, 3 , 379-390. https://doi.org/10.1093/japr/3.4.379

[19] Stilborn, H.L., Moran, Jr., E.T., Gous, R.M. and Harrison, M.D. (1997) Effect of Age on Feather Amino Acid Content in Two Broiler Strain Crosses and Sexes. The Journal of Applied Poultry Research, 6, 205-209. https://doi.org/10.1093/japr/6.2.205

[20] Smith, W.K. and Bath, H.M. (1995) Growth and Composition of Feathers in Male Broilers. British Poultry Science, 36, 874.

[21] Conde-Aguilera, J.A., Cobo-Ortega, C., Tesseraud, S., Lessire, M., Mercier, Y. and van Milgen, J. (2013) Changes in Body Composition in Broilers by a Sulphur Amino Acid Deficiency during Growth. Poultry Science, 92, 1266-1275.

https://doi.org/10.3382/ps.2012-02796

[22] Gruhn, K. and Anke, M. (1965) Veränderungen des Rohnährstoff-, Aminosäureund Mineralstoffgehaltes beim Huhn während der Entwicklung vom Eintagsküken zur Junghenne. [Crude Nutrient, Amino Acid and Mineral Content Variations in Fowl Developing from Day-Old Chicken to Young Hen.] Archiv für Tierernährung, 15, 147-158. https://doi.org/10.1080/17450396509423119

[23] Leclercq, B., Chagneau, A.M., Cochard, T. and Khoury, J. (1994) Comparative Responses of Genetically Lean and Fat Chickens to Lysine, Arginine and Non-Essential Amino Acid Supply. I. Growth and Body Composition. British Poultry Science, 35, 687-696. https://doi.org/10.1080/00071669408417735 
[24] Leong, K.C., Sunde, M.L., Bird, H.R. and Elvehjem, C.A. (1959) Interrelationship among Dietary Energy, Protein, and Amino Acids for Chickens. Poultry Science, 38, 1267-1285. https://doi.org/10.3382/ps.0381267

[25] Kirchgeßner, M., Roth-Maier, D.A. and Gerum, J. (1978) Body Composition and Nutrient Deposition of 3-5 Week Old Broilers With Varying Energy and Protein Supply. Archiv für Geflügelkunde, 42, 62-69. (In German)

[26] Rosebrough, R.W. and Steele, N.C. (1985) Energy and Protein Relationships in the Broiler. 1. Effect of Protein Levels and Feeding Regimens on Growth, Body Composition, and in Vitro Lipogenesis of Boiler Chicks. Poultry Science, 64, 119-126. https://doi.org/10.3382/ps.0640119

[27] Summers, J.D., Spratt, D. and Atkinson, J.L. (1992) Broiler Weight Gain and Carcass Composition when Fed Diets Varying in Amino Acid Balance, Dietary Energy, and Protein Level. Poultry Science, 71, 263-273. https://doi.org/10.3382/ps.0710263

[28] Holsheimer, J.P. and Ruesink, E.W. (1993) Effect on Performance, Carcass Composition, Yield, and Financial Return of Dietary Energy and Lysine Levels in Starter and Finisher Diets Fed to Broilers. Poultry Science, 72, 806-815.

https://doi.org/10.3382/ps.0720806

[29] Twinging, Jr., P.V., Thomas, O.P. and Bossard, E.H. (1978) Effect of Diet and Type of Birds on the Carcass Composition of Broilers at 28, 49, and 59 Days of Age. Poultry Science, 57, 492-497. https://doi.org/10.3382/ps.0570492

[30] Geraert, P.A., Macleod, M.G., Larbier, M. and Leclercq, B. (1990) Nitrogen Metabolism in Genetically Fat and Lean Chickens. Poultry Science, 69, 1911-1921. https://doi.org/10.3382/ps.0691911

[31] Ajang, O.A., Prijono, S. and Smith, W.K. (1993) Effect of Dietary Protein Content on Growth and Body Composition of Fast and Slow Feathering Broiler Chickens. British Poultry Science, 34, 73-91. https://doi.org/10.1080/00071669308417564

[32] Alleman, F., Michel, J., Chagneau, A.M. and Leclercq, B. (2000) The Effects of Dietary Protein Independent of Essential Amino Acids on Growth and Body Composition in Genetically Lean and Fat Chickens. British Poultry Science, 41, 214-218. https://doi.org/10.1080/713654902

[33] Corzo, A., Kidd, M.T., Burnham, D.J., Miller, E.R., Branton, S.L. and Gonzalez-Esquerra, R. (2005) Dietary Amino Acid Density Effects on Growth and Carcass of Broilers Differing in Strain Cross and Sex. The Journal of Applied Poultry Research, 14, 1-9. https://doi.org/10.1093/japr/14.1.1

[34] Somes, Jr., R.G. and Johnson, S. (1982) The Effect of Scaleless Gene, sc, on Growth Performance and Carcass Composition of Broilers. Poultry Science, 61, 414-423. https://doi.org/10.3382/ps.0610414

[35] Cahaner, A. and Leenstra, F. (1992) Effect of High Temperature on Growth and Efficiency of Male and Female Broilers from Lines Selected for High Weight Gain, Favourable Feed Conversion, and High or Low Fat Content. Poultry Science, 71, 1237-1250. https://doi.org/10.3382/ps.0711237

[36] Gous, R.M., Moran, Jr., E.T., Stilborn, H.R., Bradford, G.D. and Emmans, G.C. (1999) Evaluation of the Parameters Needed to Describe the Overall Growth, the Chemical Growth, and the Growth of Feathers and Breast Muscles of Broilers. Poultry Science, 78, 812-821. https://doi.org/10.1093/ps/78.6.812

[37] Khan, D.R., Wecke, C. and Liebert, F. (2014) Amino Acid Composition of Body Protein in Naked Neck Meat Type Chickens Depending on Age, Gender and Genotype. Proceedings of the Society of Nutrition Physiology, 26, 128.

[38] Plavnik, I. and Hurwitz, S. (1983) Organ Weights and Body Composition in Chick- 
ens as Related to the Energy and Amino Acid Requirements: Effect of Strain, Sex, and Age. Poultry Science, 62, 152-163. https://doi.org/10.3382/ps.0620152

[39] Süto, Z., Horn, P., Jensen, J.F., Sørensen, P. and Csapo, J. (1998) Carcass Traits, Abdominal Fat Deposition and Chemical Composition of Commercial Meat Type Chicken during a Twenty Week Growing Period. Archiv für Geflügelkunde, 62, 21-25.

[40] Moran, Jr., E.T. and Bilgili, S.F. (1990) Processing Losses, Carcass Quality, and Meat Yields of Broiler Chickens Receiving Diets Marginally Deficient to Adequate in Lysine Prior to Marketing. Poultry Science, 69, 702-710.

https://doi.org/10.3382/ps.0690702 